\title{
The Demographic Factor in China's Transition ${ }^{1}$
}

\author{
WANG Feng and Andrew Mason
}

During the last two and a half decades, China has witnessed demographic change of historic proportions. It has transformed from a "demographic transitional" society, one where reductions in mortality led to rapid population growth and subsequent reductions in fertility led to slower population growth, to a "posttransitional" society, where life expectancy has reached new heights, fertility has declined to below-replacement level, and rapid population aging is on the horizon. In the nottoo-distant future - in a matter of a few decades - China's population will start to shrink, an unprecedented demographic turn in its history in the absence of massive wars, epidemics, and famines. In this process, China will also lose its position as the most populous country in the world.

Demographic changes in China are monumental for reasons in addition to the shifts in traditional demographic parameters - mortality, fertility, population growth rate, and age structure. During its economic transitions of the last two and a half decades, China has also seen migration and urbanization processes that are unprecedented in world history for their sheer magnitudes. Population redistribution is inextricably tied to the broad social and economic transitions that China has undergone, and at the same time, it has also shaped important underlying conditions, as opportunities and constraints, for China's economic transition.

At the start of China's economic reform in the late 1970s, the post-Mao Chinese leadership established population control as one of its top policy priorities. Having witnessed rapid population growth during the preceding decades, the leadership believed population control to be a key measure for ensuring growth in per capita income - its new political mandate. Discourse on population control led to the framing of population growth as the root of all evils, shifting public attention to "overpopulation" and away from political and social problems of the late socialist era. This neo-Malthusian perspective (Lee and Wang, 1999) led to the elevation of

1 The authors thank Robert Retherford, Yong Cai, Fang Cai, Martin K. Whyte, and Kam Wing Chan for helpful suggestions and Maliki, Comfort Sumida, and Turro Wongkaren for their research assistance. Mason's research was supported in part by NIA, R01-AG025488-01. 
population control, along with economic reform, as a "basic state policy" and to the implementation of the draconian policy of one child per couple (Wang, 2005).

Two and a half decades later, following China's success in its transition to a market economy and its phenomenal economic growth, public discourse about the adverse development effects of China's large population has faded from view. The discussion, to the extent that it still exists, has shifted to environmental and natural resource issues, subsumed under a new mantle of "sustainable development." The demographic factor, curiously, is virtually being "counted out" insofar as its relationship with economic development is concerned. Despite the change in discourse, economic success, achievement of low fertility, slower population growth, and a rapidly aging population age structure, China's population policy has remained largely intact. The lack of a serious examination of China's demographic realities and its current population policy, just as the lack of a serious debate on China's draconian population-control policy two and a half decades ago, denies the Chinese public and its policymakers the opportunity to understand fully the role demographic factors have played in China's economic transition in the past, and the role it will play in the future.

In this chapter, we focus on three aspects of China's demographic change during its economic reforms of the past quarter century. First, we review and summarize major demographic changes in China during this time period. Second, we consider whether China's economy experienced a "demographic dividend" that complemented other favorable development forces during the past quarter century. We also consider how future economic prospects are likely to be influenced by demographic factors. Third, we identify and highlight a number of the social consequences of China's recent demographic changes.

\section{TWO AND A HALF DECADES OF DEMOGRAPHIC CHANGE}

Substantial reductions in death- and birthrates predate the implementation of economic reform programs in the late 1970s. ${ }^{2}$ Impressive mortality declines raised life expectancy by more than 50 percent, from the low forties to the high sixties, between 1950 and 1982, the first post-reform year for which data are available (Table 5.1). ${ }^{3}$ Under the government's family-planning program that promoted later marriages, fewer births, and longer birth intervals (wan, xi, and shao), the

${ }^{2}$ For a review of demographic changes up to the late 1980s, see Lavely, Lee, and Wang (1990). A more in-depth summary and analysis of the Chinese demographic behaviors can be found in Lee and Wang (1999). Scharping (2003a) provides a comprehensive review and analysis of China's birth-control programs.

${ }^{3}$ No reliable estimates of life expectancy exist for the early 1950s. Available estimates of life expectancy at birth based on census and mortality survey data give 42.2 for males and 45.6 for females for the period of 1953-1964 (Banister and Preston, 1981; Coale, 1984). Mortality estimates based on a retrospective fertility history survey conducted in 1987, consisting of a two-per-thousand sample of China's population, reported life expectancy of 37.9 and 40.0 for the period of 1945-1949 and 46.7 and 49.2 for 1950-1954, for males and females separately 
Table 5.1. Summary demographic indicators, China, 1950-2000

\begin{tabular}{lcccr}
\hline \hline & \multicolumn{4}{c}{ Year } \\
\cline { 2 - 5 } Indicator & 1950 & 1982 & 1990 & 2000 \\
\hline Population size (millions) & 551.96 & $1,016.54$ & $1,143.33$ & $1,265.83$ \\
Percent urban & 11.18 & 21.13 & 26.41 & 36.22 \\
Birthrate (per thousand) & 37.0 & 22.28 & 21.06 & 14.03 \\
Death rate & 18.0 & 6.6 & 6.67 & 6.45 \\
Rate of natural increase & 19.00 & 15.68 & 14.39 & 7.58 \\
TFR & - & 2.9 & 2.3 & 1.6 \\
Mean age at first marriage (F) & - & 22.4 & 22.1 & 24.15 \\
Life expectancy (M) & 42.2 & 66.43 & 66.91 & 71.01 \\
Life expectancy (F) & 45.6 & 69.35 & 69.99 & 74.77 \\
Infant mortality rate (M) & 145.85 & 36.47 & 32.19 & 20.78 \\
Infant mortality rate (F) & 130.18 & 34.54 & 36.83 & 29.15 \\
Mean household size & - & 4.41 & 3.96 & 3.44 \\
\hline
\end{tabular}

Sources and notes: ${ }^{*}$ indicates authors' estimate. Population size, percent urban, and crude vital rates are from various published official Chinese sources; TFR before 1995 are from China Population Yearbook (1995 and 2000; see discussions in the text); marriage age from China Population Yearbook (2003); life expectancy under 1950 is for 1953-1964 and is from Coale (1984); infant mortality rates under 1950 are for 1950-1954 and are from Yan and Chen (1993); other mortality numbers are from Li and Sun (2003).

female mean age at first marriage rose from 19.7 to 22.8 during the 1970 s. The total fertility rate (TFR) declined from 5.7 births per woman in 1970 to 2.8 births per woman in 1979 (Coale and Chen, 1987). ${ }^{4}$ By international standards, China had by and large completed its fertility transition, in the absence of its more recent one-child policy, by the time its economic reforms began at the end of the 1970s.

Such extraordinary demographic accomplishments did not deter the post-Mao Chinese leadership from adopting a population policy that was in sharp contrast to its economic policy. Economic reforms over the last two decades gradually relaxed the state's control and returned the right of decision making to families and individuals. Population policy, on the other hand, further asserted the right of the state to regulate reproductive decision making that previously had been reserved for couples and their families. In 1980, the one-child-per-couple policy was formally announced and promoted nationwide. Popular resistance led to subsequent policy modifications in the 1980s and spared much of rural China from the one-child policy by allowing them a second child (Greenhalgh, 1986). Urban China has been subject to a strict one-child policy for twenty-five years, despite the initial claim that this was to be an emergency measure. Continued state intervention in reproduction,

(Yan and Chen, 1993). These estimates, however, have only limited value, given the nature of the data and the methods by which these estimates were created.

4 The total fertility rate is the average number of births per woman, given current age-specific birthrates. 
in combination with the state's withdrawal from economic and migration control, forms the important institutional background for China's demographic changes of the last two and a half decades.

\section{Institutional Background of Demographic Change}

Three sets of institutional changes are crucial to understanding the demographic changes occurring in China since the late 1970s. First, economic and social reforms have shifted the locus of economic decision making from the state to the family and the individual. Second, a strict birth-control policy, with a recent important reorientation of family-planning programs, remains in place. Third, a fundamental shift in migration policy has allowed people to move freely across administrative boundaries.

In sharp contrast to the socialist planned economy era, when much of the cost of childbearing was assumed by either the state or the collective, China's emerging market economy has increasingly placed the financial burden of raising children on the shoulders of the Chinese family. Such changes have profound impacts on behaviors that relate to demographic changes, ranging from health care and mortality, to marriage, fertility, and living arrangements. Dissolution of collective farming in rural China and termination of guaranteed lifetime employment in urban China increased economic risks among adult Chinese and posed serious concerns for parents planning for their children's economic livelihood. Emergence of a labor market that rewards human capital has clearly intensified the desire and competition to provide increased and improved schooling for children. With the end of free education, beyond the government's nine-year compulsory schooling requirement, the cost of education has skyrocketed. Collapse of the rural public health system and abolition of free health care in urban areas have added health care cost as a substantial expenditure borne by Chinese families. Finally, an emerging consumer culture is also encouraging Chinese households to divert expenditures from rearing children to investment in and expenditures on housing, automobile, consumer durables, clothing, and recreational activities (Davis, 2000).

The impact of institutional changes associated with economic reform on demographic behavior is difficult to assess in light of another set of institutional factors: the Chinese government's continued policy and efforts in controlling population growth. Already two and a half decades into its implementation, China has not signaled if and when it would phase out its one-child policy. The most important change in China's birth-control program in the past decade has been improvements in how the program is implemented, not changes to the policy itself. Starting in the mid-1990s, implementation of the birth-control program has shifted from pure reliance on administrative coercion to greater emphasis on service provision (Winkler, 2002; Kaufman, 2003; Merli, Qian, and Smith, 2004). Stringency of the birth-planning policy is revealed by a recent analysis of fertility policies at local levels. By aggregating fertility policies of more than 400 prefectures, the authors 
report that at the end of the 1990s, the national fertility level as stipulated by local policies should be 1.47, well below the replacement level of 2.1. According to these policies, the majority of Chinese couples, 63.1 percent, could have only one child, 35.6 could have two children, and 1.3 percent could have three children (Wang, 2005; Gu et al. 2007)..$^{5}$ Moreover, the political pressure generated by a 1991 policy that links birth-control achievement to cadre evaluation has not only encouraged local officials to compete for lower birthrates within their jurisdictions (Greenhalgh, Zhu, and Li, 1994), but also resulted in false statistics that have corrupted the nationwide birth-reporting system (Smith, 1994; Zeng, 1996; Merli, 1998; Merli and Raftery, 2000; Scharping, 2003, 2007).

Chinese demographic behaviors of the last quarter century are further affected by a third important institutional change, the huge increase in domestic labor migration following the government's reversal of its earlier migration-control policy. The massive volume of migrants from the Chinese countryside to cities, and between cities and rural areas, has not only fueled China's economic growth, but also brought a number of far-reaching demographic consequences. The role of migration in demographic processes goes far beyond its simple effect of damping fertility by separating young couples. Young and unmarried women and men often choose better earning opportunities over marriage and having children early in their lives. Migration exposed many to the urban consumer culture and the urban low-fertility environment. At the same time, as often portrayed by the Chinese official media, population migration has made monitoring and controlling births more difficult. Migration opportunities have also resulted in a new household division of labor and new living arrangements at both the origin and the destination.

\section{Major Indicators of Demographic Change}

\section{Population Growth and Fertility}

Despite the low fertility level already achieved on the eve of China's economic reforms, China experienced a substantial population increase. This increase was due to population momentum resulting from a large number of young people entering the reproductive ages, itself a result of the high fertility and declining mortality of the 1960s and 1970s. Between 1978 and 2000, China's total population rose from less than 1 billion to more than 1.25 billion, a net increase of 31.5 percent. The population added during these two decades, slightly over 300 million, is roughly equal to the increase during the two preceding decades. The rate of population growth during the 1980s and the 1990s, however, was the slowest in the life span of the People's Republic. During the three decades between 1950 and 1980,

${ }^{5}$ Couples who could have only one child include those who reside in the one-child policy regions, comprising 35.4 of China's population, and those who reside in 1.5 children policy regions but could have only one child because their first child is a son. More than half of China's population, 53.6 percent, live in regions with a 1.5 children policy, where a couple whose first child is a daughter is allowed to have a second birth (Gu et al., 2007). 
the population grew at annual rates of $1.82,2.26$, and 1.73 percent each decade. The growth slowed to 1.46 percent per year in the 1980 s and 1.02 percent in the 1990 s. $^{6}$

While it can be said with certainty that China's population growth rate has declined to low levels, the exact level of Chinese fertility cannot be stated with the same degree of confidence, primarily due to a virtual collapse of the birth-reporting system in the 1990s. In the 1980s, demographic variables were measured with great detail and accuracy. By the 1990s, few could trust demographic data, particularly fertility data, which were collected and released by government agencies. From the early 1990s, scholars report as many as 30 percent of births were not counted by the family-planning-registration system in selected locales. Problems in birth reporting and registration started to spread to other official demographic datagathering sources, including the midterm census, annual population surveys, and special fertility surveys. China's 2000 census, while asserting an underreporting rate of only 1.8 percent, itself a sixfold increase from the 1990 census, revealed many apparent anomalies. For instance, the survival ratio between 1990 and 2000 aged 0-4 in 1990 was found to be 1.05 for males and 1.07 for females, suggesting either undercounting of births in the 1990 census or, less likely, double counting in the 2000 census ( $\mathrm{Li}$ and Sun, 2003, p. 38). In addition, most survival ratios for groups aged 20-29 in 1990 exceed 1.0, an impossible demographic outcome in the absence of flawed data (or significant in-migration). Not long into the 1990s, the two main government agencies responsible for collecting fertility information, the State Family Planning Commission and the National Bureau of Statistics, simply gave up their attempt to provide reliable and detailed information on fertility. Instead, fertility was reported to be "around the replacement level of 2.1 births per woman."

The most recent official report of China's fertility level came with the 2000 population census, but with a number that caused more controversy than comfort. The census reported a TFR of 1.22 for China as a whole. While releasing such a number showed courage and candidness on the part of census personnel, no one in China, including the data collectors, believes it. Such a low number would put Chinese fertility at a level on par with Italy, lower than Japan, and at about a third of the level for less developed countries. ${ }^{7}$ This result was both a surprise and an embarrassment, because it came after repeated government appeals to report births accurately in the census and despite promises of not punishing those who disclosed previously unreported births. It also confirmed the long-held suspicion that government-released fertility numbers were no longer to be trusted. In a careful political and demographic analysis of six Chinese sources that release fertility

${ }^{6}$ These rates are calculated based on annual population numbers published in official Chinese statistical sources.

7 China excluded from the group of less developed countries. Data for other countries or region are from the Population Reference Bureau, at http://www.prb.org. 
numbers, Scharping (2007) makes a convincing case for confusion and messiness in Chinese fertility statistics.

The demise of the Chinese fertility-data-gathering system and the unbelievably low fertility numbers based on official statistics should not be used to dismiss the possibility of any genuine fertility reduction in recent years. While the Chinese fertility level in the 1980s showed only a modest downward movement in spite of the forceful implementation of the one-child policy (Feeney and Wang, 1993), a number of arguments have been made to suggest that in the 1990s fertility declines were greater. The broad economic changes in the society and a continued stringent population-control policy combined have further affected Chinese young couples' fertility preferences (Merli and Smith, 2002). A direct piece of evidence to such a change is the postponement of marriage and childbearing in recent years. As shown in Table 5.1, the average age at first marriage for females rose by nearly 10 percent in the 1990s, from 22 to 24 . Postponement of childbearing due to delayed marriage and further delaying within marriage can result in a substantial reduction in the total fertility level and the number of births (Guo, 2000; Guo and Chen, 2007). Also, while some still believe that current Chinese fertility, at around 1.8 births per woman, remains at a level not far below replacement, others have maintained that this number is simply too high (Zhang and Yuan, 2004; Zhang and Zhao, 2006; Guo and Chen, 2007). Among other reasons, a simple argument is that if the national TFR is indeed at a level of 1.8 , it would imply that the 2000 census missed a third of all births nationwide, a possibility not many are willing to accept. Moreover, results from three recent and careful analyses all suggest that the fertility level is around 1.6 children per woman (Cai, forthcoming; Retherford et al., 2005; Zhang and Zhao, 2006).

\section{Mortality and Health}

Dissolution of the rural public health care system and reform of the urban public health care system raised concerns at the start of the reform about their potential detrimental effect on Chinese health statuses. Early concerns focused particularly on infant and child health, as immunization and other basic care had previously been delivered largely by the public health care system. Indeed, mortality improvements stalled during the 1980s (Table 5.1). During the 1990s, however, mortality decline continued at a pace similar to that found in other developing countries. Life expectancy increased by about four years for both men and women during the decade. The level of life expectancy in 2000, 71 years for males and almost 75 for females, is well above the average level for less developed countries (61 and 64 in 2003, respectively) and approaching that of developed countries (72 and 79 for males and females, respectively; http://www.prb.org). A major contributor to improvements in life expectancy has been a further reduction in infant mortality.

There are, however, strong reasons to believe that these most recent mortality numbers are too rosy due to underreporting of deaths in the 2000 census (Li and Sun, 2003). Hence, it is difficult to assess the extent to which mortality conditions 
improved during the 1990s, and it is possible that the gains were more moderate than what is revealed by the 2000 census. Among its many important effects, China's continued one-child policy may have had a negative impact on female infant and child survival, an issue we will return to in a later section of the chapter. An even more difficult issue to assess is the extent to which reform of the health care system accounted for the slower declines in mortality.

\section{Migration and Urbanization}

In contrast to fertility and mortality declines that began before China's reforms, increased migration and an accompanying urbanization process are clearly the products of the reform era. This is especially the case for a new category of migrants called the floating population, a unique product of the Chinese political economy system. Constrained by a number of institutional arrangements, ranging from household registration control to the land tenure system, these migrants leave their place of residence for employment elsewhere but do not change their place of household registration or their place of permanent residence. They are therefore migrants who float on the surface of society (Chan and Zhang, 1999; Solinger, 1999; Wang, Zuo, and Ruan, 2002). Over the past two decades, it is the drastic increase of migrants in this category that has accounted for the rapid increase in the overall volume of migrants. At the start of the reforms, the number of Chinese migrants in comparison to its total population was minuscule. Even in 1987, when the Chinese census first included information on migration, only 15.2 million out of over 1 billion, or about 1.5 percent, reported themselves to be migrants away from their place of household registration for more than six months (Chan, 2001, p. 131). By 1990, the size of this population increased to 30 million and by 1995, 56 million. The 2000 census counted 80 million Chinese as members of the floating population. Including migrants who had spent less than six months at their destination would put the estimated number of temporary migrants at 120 million, up from 88.5 million in 1995 (Liang, 2003). Similarly, the annual population sample survey conducted by China's National Bureau of Statistics reports that in 2002, one out of every ten persons was living in a place (town, township, or subdistrict) that was not the location of the person's household registration. In the economically most dynamic regions of China, such as Guangdong, Fujian, Shanghai, and Beijing, 20-30 percent of current residents had household registrations elsewhere. ${ }^{8}$ Urban population growth during the 1990s was also one of the most rapid in China's history, with a net gain in the urban population of 157 million. This increase almost equals the sum of the preceding four decades combined. Massive ruralurban migration was the most important force for urbanization, accounting for 60 percent of all urban population growth during the 1990s (Chan and $\mathrm{Hu}, 2003) .{ }^{9}$

8 Calculated from Yearbook (2003, p. 102).

9 The remainder of the growth was roughly equally attributed to rural to urban reclassification and urban natural population growth (Chan and $\mathrm{Hu}, 2003$ ). 


\section{Household Type and Living Arrangement}

Decreased fertility, increased life expectancy, and increased migration have also contributed to notable changes in the size and composition of Chinese households. In 1982, a history of high fertility, housing shortages, and other conditions led to an average household size of 4.4. By 2000, the average household size had declined to 3.4 (Table 5.1). For urban China, the average household size was barely above 3 , reflecting both the rapid decline in fertility over the last two and a half decades and changing preferences in living arrangements.

A major contributing factor to the decline in household size has been an increase in the number of one-couple households, not a reduction in the number of multiple-generation households (those with three generations or more). Onegeneration households rose from 4.7 percent of all Chinese households in 1982 to 12.7 percent in 2000 . As a result of this change, the percentage of households that are one generation (including both one-couple and one-person households) rose from 13.9 in 1982 and 13.5 in 1990 to 22.3 in 2000 . While the percentage of three- or more generation households scarcely changed, the share of two-generation households dropped from 66.6 in 1982 to 55.9 in 2000 (Zeng and Wang, 2003). Many of these newly emerged one-generation households are Chinese elderly who live by themselves. In 1982, 10.7 percent of the male elderly population aged 65 and above lived alone, 16.9 percent lived with a spouse only, and 67.9 percent lived with their children. By 2000, these numbers had changed to 8.4, 28.8, and 59.9 percent respectively. Similar changes are also seen for the female elderly population, but with a higher share living alone than males: 13.7 percent in 1982 and 10.7 percent in 2000. In urban China, households with elderly only are more prevalent, with 33.7 percent of the male elderly living with only a spouse in 2000 and only 55.8 percent living with their children (Zeng and Wang, 2003).

\section{IS CHINA'S FERTILITY DECLINE YIELDING DIVIDENDS?}

The rationale for China's one-child policy was a neo-Malthusian perspective on the relationship between population and development, a view largely dismissed by mainstream economists. The architects of China's population policy can point, however, to the post-reform economic record as evidence of the success of the policy. This assertion can be questioned on two grounds. The first, discussed earlier, is the extent to which the transition to low fertility was accelerated by the one-child policy. The second, considered in this section, is the extent to which fertility decline, the slowdown in population growth, and changes in age structure contributed to China's economic success.

The demographic transition interacts with a fundamental feature of any economy - its life cycle variation in consumption and production. Humans have an extended period of economic dependency at the beginning of their lives and, in modern industrial societies, at the end. During these ages of dependency or deficit ages, individuals on average consume more than they produce. During the prime working ages or surplus ages, individuals produce more than they consume. 
(a)

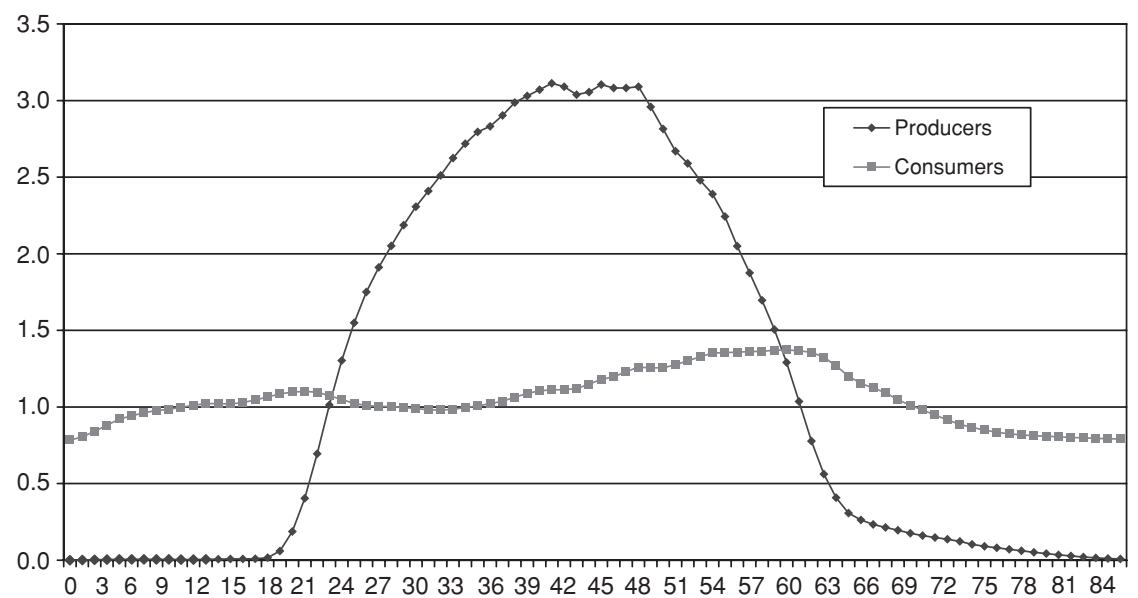

(b)

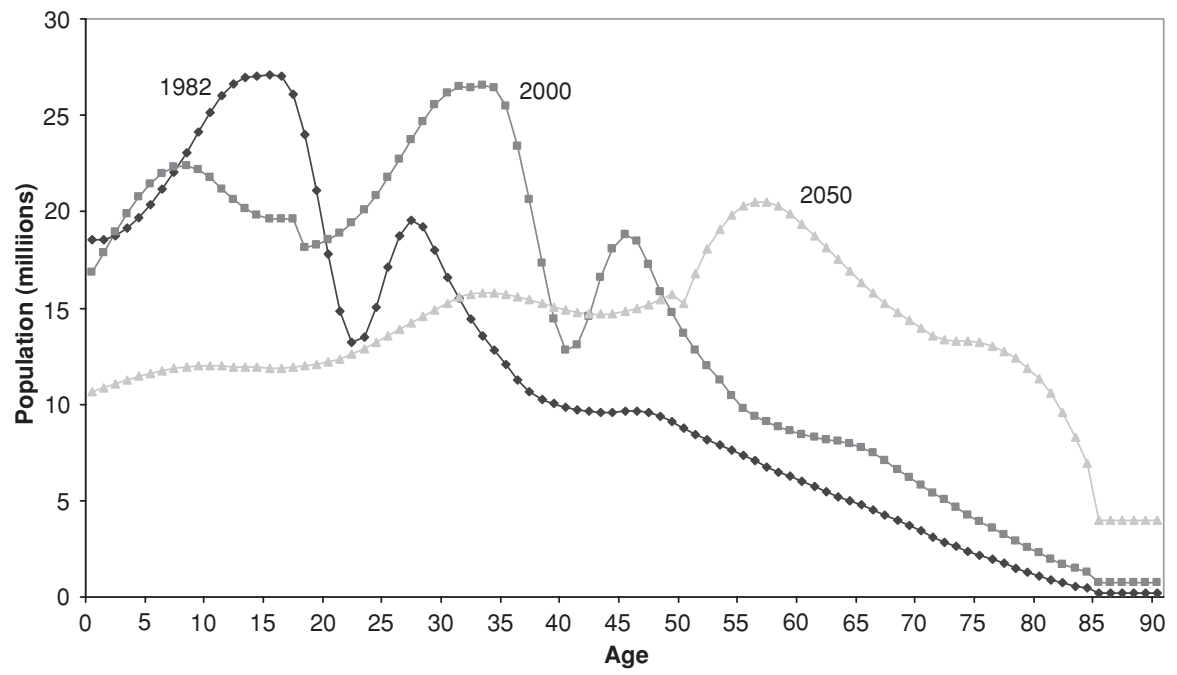

Figure 5.1. (a) Age profiles of consumption and production, urban China, 2000 (Note: Profiles normalized to total to one hundred. Source: China National Bureau of Statistics, 2000.); (b) Population by age, China, 1982, 2000, and 2050 (Note: Population 85 and older uniformally distributed in the $85-90$ age groups. See text for sources and methods.)

Detailed information about the life cycle of production and consumption in China is limited. However, the estimated profiles for urban China in 2000 (Figure 5.1a) are similar to those found in other countries. ${ }^{10}$

10 The production and consumption values given in Figure 5.1a are estimated from the 2000 Urban Family Income and Expenditure Survey for China. Both profiles are normalized to aggregate to 100. Details of the estimation procedure are available from the authors. 
Unlike many other populations in the world, China's population age profiles contain drastic fluctuations resulting from its unique histories of fertility and mortality change. As shown in Figure 5.1b, in 1982 China's population age profile reveals a clear deficit among those aged around 23, a direct result of the Great Leap Forward famine of 1959-1961. The famine was followed by a baby boom during much of the 1960s, leading to the excess population aged roughly 15-20 in 1982. Fertility decline starting in the early 1970s, meanwhile, resulted in a steady decline in the number of annual births, as shown by the reduction in the number of people from around age 10 and below. These relatively large and small birth cohorts, as well as other fluctuations in the population age structure, are carried over to year 2000 and 2050 (projected).

The divergence between production and consumption interacts with changes in population age structure to generate what is called a demographic dividend (Bloom and Williamson, 1998; Mason, 2001; Bloom et al., 2002) or more recently described as two demographic dividends (Mason and Lee, 2006). The first dividend arises because the demographic transition induces changes in population age structure that raise the share of the population concentrated at the productive ages. The second dividend arises as individual behavior and public policy respond to anticipated changes in population age structure, for example, increases in the importance of retirement, as discussed in more detail later. An important point that is emphasized later is that the demographic dividends are not independent of the policy environment in which population change is occurring, especially in China.

\section{The First Dividend}

The first dividend measures increases in income per capita that occur because the productive population is growing at a faster rate than the total population over part of the demographic transition (for details, see the Appendix to this chapter). The dividend is not always positive, however. As the demographic transition proceeds, growth in the working-age population will be slow relative to the retired population. The effect will be to depress growth in per capita output or per capita consumption.

Analysis that emphasizes only the variation in productivity with age is incomplete. Consumption also varies with age. If the population share of age groups with low productivity and high consumption increases, the aggregate effects are magnified in comparison to the consequences of an increased share for an age group with low productivity and low consumption. Thus, the analysis presented here uses the support ratio - the ratio of the effective number of producers to the effective number of consumers - to quantify the first dividend (Mason and Lee, forthcoming). The support ratio is the ratio of the effective number of workers (weighted by age-specific productivity) to the effective number of consumers (weighted to allow for variation in consumption by age) (Cutler et al., 
1990). ${ }^{11}$ Given age profiles of productivity and consumption, output per effective consumer increases at the same rate as the support ratio grows, which depends, in turn, entirely on changes in population age structure.

The magnitude and sign of the first dividend vary substantially over three periods that can be clearly distinguished (Figure 5.2a). From 1982 to 2000, the demographic dividend was especially favorable, as changes in the support ratio had a strong positive effect on output per capita. The support ratio increased by 28 percent or at an average annual rate of 1.3 percent (Figure 5.2a). During the same period, real gross domestic product (GDP) per capita (purchasing-power parity adjusted) grew at an annual rate of 8.4 percent per year (World Bank, 2004). Thus, the first demographic dividend accounted for 15 percent of China's economic growth between 1982 and 2000 .

For the most part, the gains from the first demographic dividend have been reaped in China. Between 2000 and 2013, the projected support ratio continues to rise but at a much slower pace. For the entire period the first dividend yields an increase in output per capita of 4.0 percent, an annual growth rate of 0.3 percent. The support ratio reaches a peak in 2013 and then begins a sustained, gradual decline. By 2050, the projected support ratio is only 85 percent of the level reached in 2013. Growth in output per capita is reduced by 0.45 percent per year between 2014 and 2050 as the first demographic dividend unwinds.

Trends in the support ratio combine changes in the effective labor force and the effective number of consumers that are of interest in their own right. These are decomposed in Figure 5.2b. The growth rate in the effective labor force-producerspeaked in the late 1980s and early 1990s at 3 percent per annum. Currently, the rate of growth is about half that at 1.5 percent per annum and declining steadily. Growth will cease altogether by 2020 and turn strongly negative thereafter.

These broad demographic trends conceal important subnational variation. In urban China, where population aging is more rapid, the supply of new labor market entrants from within cities has already started to shrink. In rural China, a more lenient birth-control policy and a later start of fertility decline imply a slower aging process and a stronger labor supply. Thus, better job growth in urban China combined with urban-rural demographic differences will continue to fuel urban-rural migration.

In China - and elsewhere - the first dividend is a persistent but ultimately transitory phenomenon. In China, output per capita is higher by about 10 percent in 2050 than in 1982 due to the first dividend. Were the projection extended further into the future, the net effect would be even smaller. The contribution to annual growth in output per worker during the roughly seven decades tracked is negligible.

11 The effective number of producers is measured using the age profile of productivity shown in Figure 5.1 to weigh the population. The effective number of consumers uses the age profile of consumers. Rural profiles are not available, although we hope to explore this more in the future (see Appendix for details). 
(a)

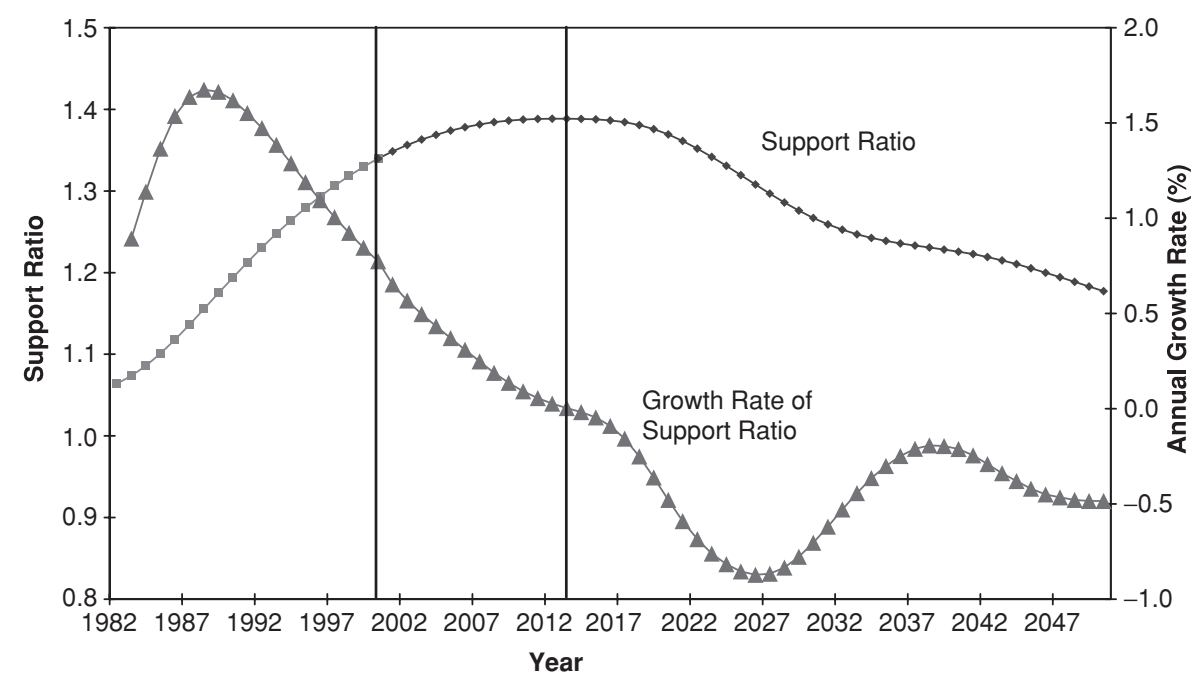

(b)

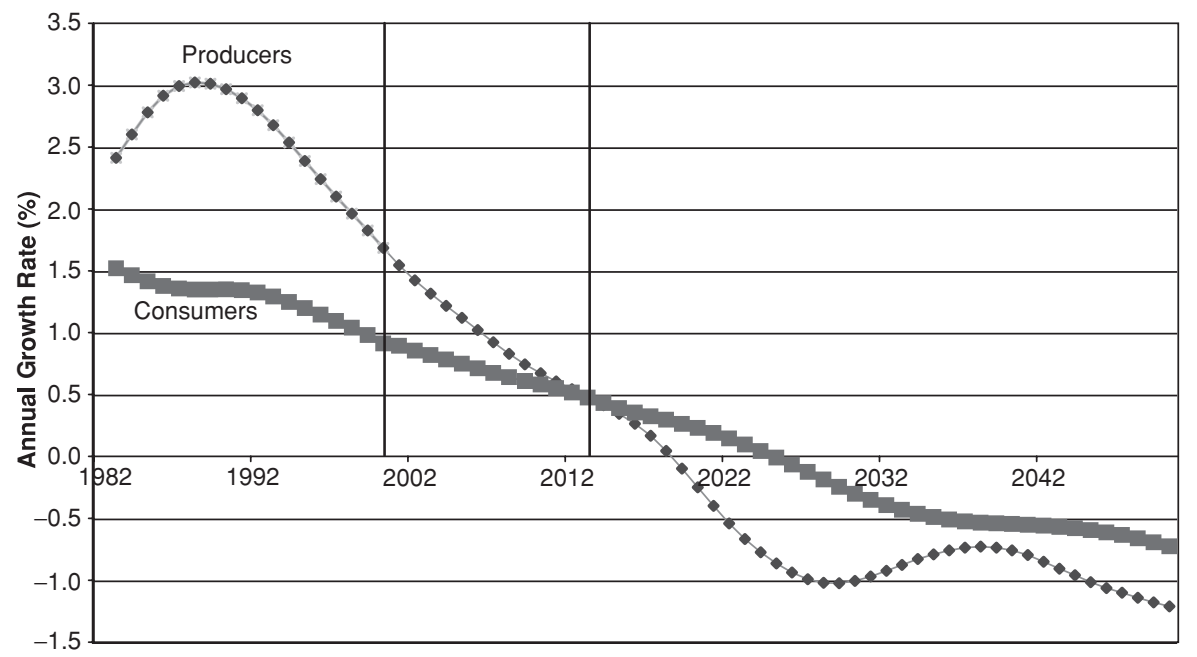

Figure 5.2. (a) Economic support ratio, China, 1982-2050; (b) Effective producers and consumers, annual growth rate, 1982-2050

However, output per capita is substantially elevated over the demographic transition. This is an event of considerable economic significance to those alive during this era. Moreover, the first dividend can have long-lasting effects if it is reinvested in the form of physical capital, human capital, and/or institutional development. This possibility is explored in more detail in the next section.

China's experience is not dissimilar to that of other East Asian economies (Mason and Lee, forthcoming). To compare China's demography with that of others, we 
Table 5.2. Average annual rate of growth in the support ratio (percent), 1982-2050, China and other selected societies

\begin{tabular}{lcccc}
\hline \hline & $1982-2000$ & $2000-2013$ & $2013-2050$ & $1982-2050$ \\
\hline China & 1.28 & 0.28 & -0.45 & 0.15 \\
Taiwan & 1.07 & 0.01 & -0.60 & -0.04 \\
Japan & -0.18 & -0.24 & -0.60 & -0.42 \\
United States & 0.44 & -0.46 & -0.04 & 0.01 \\
France & 0.40 & -0.41 & -0.17 & -0.06 \\
\hline
\end{tabular}

Note: All values calculated using the income and consumption profiles for 1999 urban China.

Source: For China population data, see text; for Taiwan population data, Department of Manpower Planning (personal communication); for Japan, the United States, and France, the United Nations (2003). Single year of age data interpolated using Sprague multipliers.

have constructed the support ratio, using the same productivity and consumption weights employed in the analysis of China, but demographic data for each of the economies shown in Table 5.2. Taiwan's pattern is very similar to China's, although its transition occurred somewhat earlier. Japan also experienced a dividend, but it came much sooner than in other East Asian countries. Throughout the 1982-2050 period, Japan's support ratio is in decline, depressing growth in per capita output by 0.4 percent per annum for the entire period. Many countries in the West also experienced rapid growth in their support ratios primarily because of the baby boom, but many, as illustrated by the experience of France and the United States, are now in a period of decline (Table 5.2).

\section{Population Aging and the Second Dividend}

The first dividend quantifies the effects of the support ratio holding output per worker constant. The second dividend arises because changes in age structure influence the processes that lead to the creation of wealth (for details, see the Appendix to this chapter). A possibility - one that has occurred in other East Asian economies - is that population aging will lead to rapid accumulation of capital. If this occurs, the capital intensity of the economy and hence, output per worker will rise. Traditionally, the effect of population on capital deepening is considered in the standard neoclassical model that assumes the saving rate is constant (Solow, 1956). The approach taken here, however, builds on elaborations of the neoclassical model that treat saving and wealth as endogenous (Tobin, 1967; Mason, 1987; Willis, 1988; Lee, 1994).

A second possibility is that population aging will produce a rapid increase in transfer wealth rather than capital. This will be the outcome if the consumption needs of retirees are met through familial or state-sponsored transfer programs. 
Such programs can effectively redistribute resources across age groups, but they do not create capital and often involve tax policies that undermine work incentives.

With increases in life expectancy, the expected duration of retirement rises. Individuals must accumulate additional wealth or face substantial reductions in standards of living during old age. This wealth can come in several forms, however. One possibility is the accumulation of additional capital. The other is the accumulation of transfer wealth - increases in the obligations of future generations to provide old-age support either through public pension plans or as part of familial support systems. Either form of wealth can meet the retirement needs of a growing elderly population, but increases in capital influence the level of output and economic growth, while increases in transfer wealth do not (Lee, 1994). A third possibility is that neither transfer wealth nor capital is accumulated. In this case, favorable effects on productivity are not achieved and standards of living among the elderly deteriorate.

The analysis presented here relies on a highly stylized model of the economy. Suppose the cross-sectional age profiles of production and consumption - the shape but not the level - are held constant. The profile of production reflects persistent effects of experience and obsolescence. We abstract from changes in labor force behavior, for example, changes in retirement behavior and changes in returns to experience related to increases in educational attainment or other forces. The profile of consumption reflects preferences about own consumption and preferences about the consumption of others, reflecting altruism or political processes.

Under these conditions, changes in China's population age structure lead to a substantial decline in the resources that must be reallocated from working generations to children and a substantial increase in the resources that must be shifted from workers to the elderly. The shift is quite evident in Figure 5.3a-c, which presents the distributions of aggregate consumption and labor income by age for 1982, 2000, and 2050 and the associated age reallocations. These charts are constructed using the profiles and population age distributions shown in Figure 5.1a,b. ${ }^{12}$

Two interage flows, from workers to children and from workers to the elderly, are summarized by the arrows shown in Figure 5.3. The foot of the arrow is located at the mean age of the outflow from workers and the head of the arrow is at the mean age of the inflow to recipients. The width of the arrow is the per capita reallocation. Given golden-rule, steady-state growth, the area of each arrow is equal to aggregate life cycle wealth that must be maintained to support each age reallocation (Lee, 1994; Lee, 2000). In the case of downward flows from older to younger age groups, the life cycle wealth is negative because those who are alive are obligated to make transfers to those who have not yet been born.

12 For a detailed discussion of the theoretical underpinnings of intergenerational transfers, see Lee (1994). 
(a)

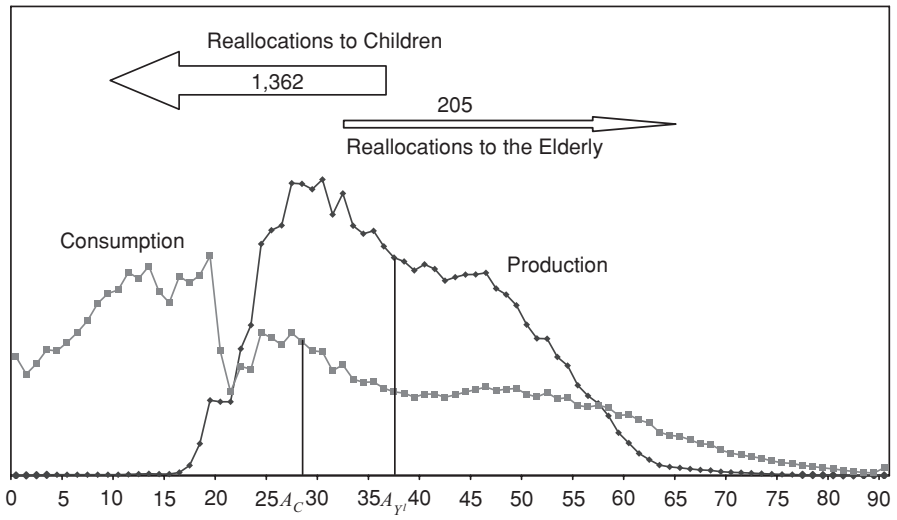

(b)

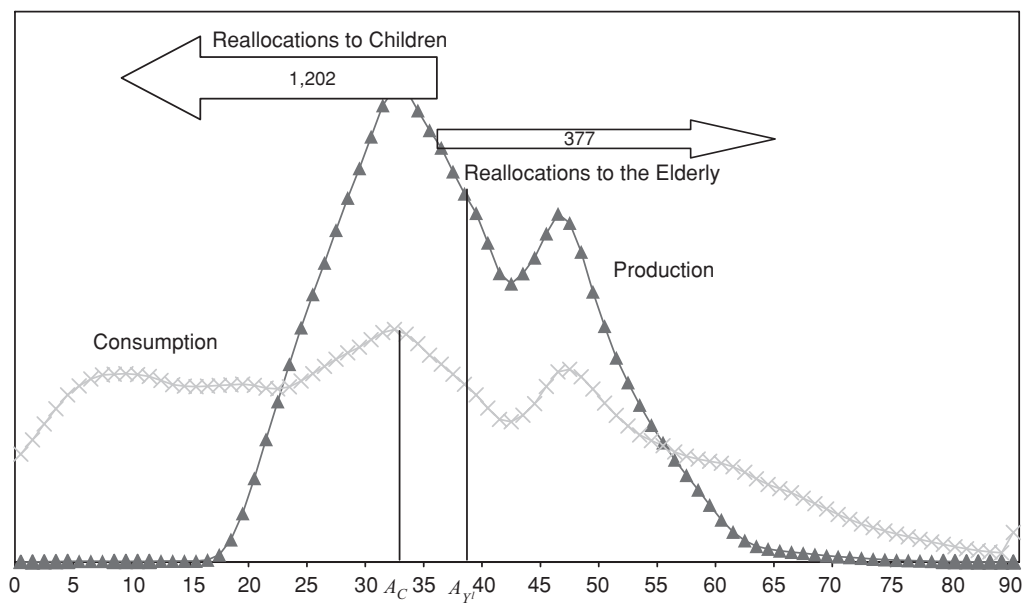

(c)

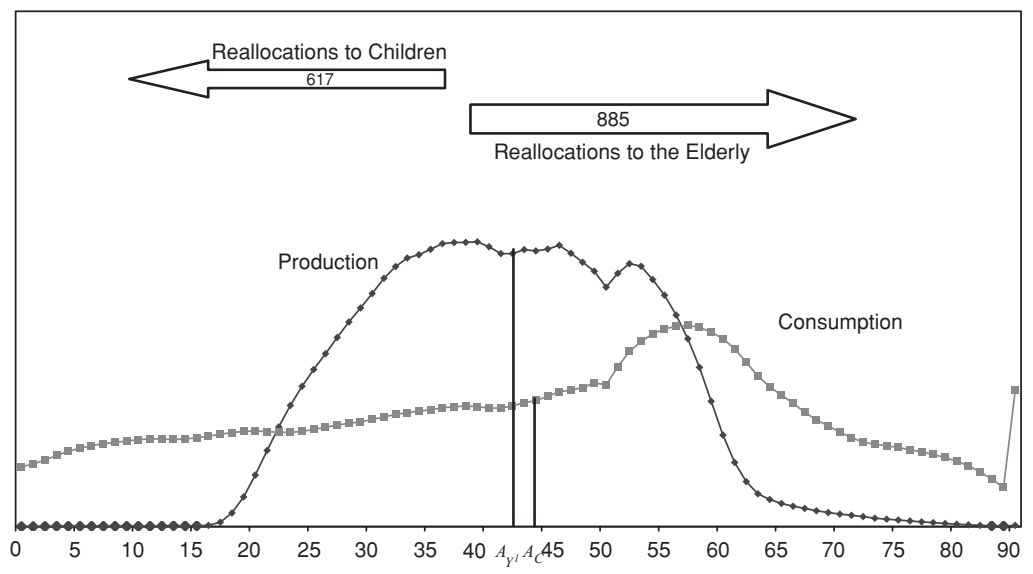

Figure 5.3. (a) Consumption and income profiles, China, 1982; (b) Consumption and income profiles, China, 2000; (c) Consumption and income profiles, China, 2050 
Table 5.3. Mean ages and life cycle wealth variables

\begin{tabular}{lrrr}
\hline \hline & 1982 & 2000 & 2050 \\
\hline Mean age of consumption & 28.0 & 32.5 & 44.4 \\
Mean age of production & 37.3 & 37.8 & 41.8 \\
Ratio of life cycle wealth to labor income & & & \\
$\quad$ TOTAL & -9.2 & -5.3 & 2.6 \\
Support of child dependents & -11.2 & -7.8 & -4.5 \\
Support of elderly dependents & 2.0 & 2.5 & 7.1 \\
\hline
\end{tabular}

Note: Calculations use age profiles of household consumption and labor income estimated from the 2000 Urban Income and Expenditure Survey. Estimate of life cycle wealth for the support of child dependents is based on the mean age at childbearing in 2000 from the population projection for China. Life cycle wealth calculations assume golden-rule, steady-state growth.

The effects of age structure on life cycle wealth are quite pronounced (Table 5.3). In 1982, transfers are strongly downward from workers to children, and total life cycle wealth is more than nine times total labor income and negative-dominated by the downward flow to children. As population aging proceeds, flows to children decline and are dominated by flows to the elderly. By 2050, steady-state life cycle wealth will be 2.6 times labor income. Steady-state life cycle wealth required to support consumption by the elderly will rise to 7.1 times labor income. The important implication of Table 5.3 is that population aging in China must lead to rapid growth in the capital stock, to an enormous expansion of public or familial-based transfer programs, or to a significant decline in living standards among the elderly.

The magnitude of the second demographic dividend thus depends on the particular mechanisms used to reallocate resources. Economic reform complicates the picture in China because the institutions and mechanisms used to achieve reallocations are a fundamental features of China's political economy.

Resources can be reallocated from surplus ages to deficit ages in different forms, relying on different institutions (Table 5.4). Three forms are available in complete economies: capital, transfers, and credit. Capital can be accumulated at surplus ages; later, at deficit ages it yields capital income and can be liquidated. An important point to note is that capital can only be used to reallocate resources from younger to older ages. Second, those in deficit ages can rely on current transfers from those in surplus ages. Third, individuals can rely on credit markets. Those at surplus ages can lend to children relying on loan repayments later in life when they are at deficit ages. Credit markets play a small role in interage reallocation systems, however, because of constraints on indebtedness. ${ }^{13}$

${ }^{13}$ Credit could play an important role if children financed their own consumption by borrowing from adults with a life cycle surplus. The debt would be repaid when children reached life cycle surplus ages and their creditors reached life cycle deficit ages. When children's consumption is 
Table 5.4. Reallocation system

\begin{tabular}{llll}
\hline \hline \multirow{2}{*}{ Form } & \multicolumn{3}{c}{ Institution } \\
\cline { 2 - 4 } Capital & \multicolumn{1}{c}{ Family } & \multicolumn{1}{c}{ Market } & \multicolumn{1}{c}{ State } \\
& $\begin{array}{l}\text { Housing } \\
\text { Consumer durables }\end{array}$ & $\begin{array}{l}\text { Factories } \\
\text { Inventories }\end{array}$ & $\begin{array}{l}\text { Public infrastructure } \\
\text { State-owned enterprise }\end{array}$ \\
Edransfers & Education & Farms & Funded pension plans \\
& $\begin{array}{l}\text { Childrearing costs } \\
\text { Support of elderly }\end{array}$ & Public debt & $\begin{array}{l}\text { Public education } \\
\text { Public health care }\end{array}$ \\
& Bequests & & Unfunded pension plans \\
Credit & Familial loans & Consumer credit & Student loans \\
\hline
\end{tabular}

Source: Adapted from Lee (1994).

In a market economy, three institutions are involved in reallocations. In many societies, the family is the principal institution responsible for reallocating resources across age groups, and in virtually all societies, families dominate reallocations to children. Two other institutions, the market and the state, vary in their importance depending on the economic system. In pre-reform China, market institutions played little or no role and the state played a dominant role. In post-reform China, the emergence of a market economy and the recognition of private property have expanded the mechanisms available for resource reallocations with important economic implications.

Suppose, throughout the entire history under consideration, that the reallocation system for the elderly relied entirely on capital. Prior to reform, this would assume that the state was implicitly funding pensions by investing in state enterprise. After reform, capital accumulation became a combined responsibility of the family, market, and state. Demographic conditions in 1982, under steadystate, golden-rule assumptions, would imply a capital-output ratio of 2.6. Demographic conditions in 2050, again under steady-state, golden-rule assumptions, imply a capital-output ratio of 7.1. Given simple assumptions, an increase in the capital-output ratio of this magnitude would lead to a doubling of output per worker. ${ }^{14}$ The impact on the rate of growth of output per worker depends on the time frame over which the capital deepening occurs. Evenly spread over a century,

financed through transfers from parents and, to a lesser extent, the state, there is little demand for credit for life cycle purposes.

14 Given a Cobb-Douglas production function, the relationship between output per worker and the capital-output ratio is

$$
\frac{Y}{L}=\left(\frac{K}{Y}\right)^{\frac{\beta}{1-\beta}}
$$

Given an elasticity of output with respect to capital $(\beta)$ of 0.35 , a rise in the capital-output ratio from 2.0 to 7.1 would produce essentially a doubling of output per worker. 
output per worker would have to grow at 0.7 percent per year. Spread over fifty years, output per worker would grow at 1.4 percent per year as a result of capital deepening. ${ }^{15}$

These calculations are suggestive and omit many complexities. One is that in pre-reform China a large portion of life cycle wealth, perhaps all, was held as transfer wealth rather than as capital. Life cycle wealth represented the pension obligations or the implicit debt of future generations as embodied in the state and its organs, for example, state-owned enterprises (SOEs). To an unknown extent, economic reform destroyed that life cycle wealth. A continuing issue in China will be through what mechanisms and to what extent life cycle wealth should be replenished. Transfer wealth will necessarily play a major role, because the greatest obligations are to those who are near or who have already reached retirement. For them, accumulating capital is not an option, only transfer wealth. The question then is the extent to which pension obligations are absorbed by the state (taxpayers), shifted to private firms including SOEs that are privatized, or shifted to families.

A second complication for China is separating the transitional issues associated with economic reform from the ongoing issues that arise with population aging. Establishing a large-scale PAYGO pension system would most readily meet the short-term objective of fulfilling obligations to current pensioners. Such a strategy, however, could commit China to a path that foregoes the second demographic dividend.

Direct econometric support for the existence of a second demographic dividend comes in the form of studies of the effect of demographic factors on aggregate saving. Saving rates must rise above their equilibrium level to produce an increase in the capital-output ratio. There is no doubt in East Asia that aggregate saving rates are well above equilibrium, but there are many competing hypotheses about why saving rates are so high in East Asian economies. A number of studies have found evidence to support the view that saving rates have been influenced by changes in age structure (Mason, 1987, 1988; Kelley and Schmidt, 1996; Higgins and Williamson, 1997; Deaton and Paxson, 2000) and life expectancy (Bloom et al., 2003; Kinugasa, 2004). The magnitudes of estimated effects are sensitive to the methods and data employed.

The available evidence supports the conclusion that the demographic transition has led to more rapid growth in output per capita in many East Asian countries where the demographic transition has been especially rapid. China has clearly enjoyed significant gains in output per effective consumer as a result of the first dividend. Whether China will enjoy a second dividend remains to be seen. Demographic change offers an opportunity for significantly more rapid economic growth, but only if the policy environment is supportive.

15 See Lee, Mason, and Miller (2003) for a dynamic simulation analysis of Taiwan. The simulated transition from a low-to-high capital-intensive economy required closer to fifty than to one hundred years. 
It would be a serious error, however, to reach any welfare conclusions about demographic change, in general, and fertility decline, in particular. Two reasons for this seem to be of particular importance and warrant emphasis. The first is that capital deepening is achieved by reduced consumption. The resulting growth in output per worker is not a free lunch but comes at the expense of reduced material standards of living among those who are saving at such high levels. The second point is that rapid fertility decline in China may have involved an enormous sacrifice on the part of parents forced to have a single child. We do not know how many children would have been born in the absence of the one-child policy. Nor do we know how to value the costs imposed by the loss of reproductive freedom.

\section{SOCIAL CONSEQUENCES OF DEMOGRAPHIC CHANGE}

In addition to the real and potential economic impacts we have examined earlier, demographic changes in China have also resulted in social consequences that will have a broad and lasting impact on Chinese society. In the foregoing paragraphs, we discussed the economic consequences of a rapid aging process in China in terms of capital accumulation and output. The same aging process will also have other economic and social consequences, including rising health care expenditure and the need for family support of the elderly. In the following, we highlight three further social consequences of China's recent demographic change: the rising sex ratio at birth and excess female infant and child mortality, social stratification in marriage, and increasing regional demographic disparities.

\section{Rising Sex Ratio and Female Child Survival}

In the past two decades, following China's one-child policy, especially the genderspecific fertility policy that permits rural couples with a firstborn daughter to have a second child, both the sex ratio at birth and the excess female infant mortality shot up (Cai and Lavely, 2003; Zhu and Li, 2003). ${ }^{16}$ In 1982, the sex ratio at birth was 108.5 , only marginally above the normal range of 104-106. After 1982, it rose sharply, to 114.1 in 1990 and 117.1 in 1995 (Figure 5.4). The most recent census reported a sex ratio at birth of 116.9 in 2000 (not shown in the figure). While some female babies are missing due to either sex-selective abortion or heightened female infant and child mortality, many are simply hidden from government officials and unrecorded in government censuses and surveys. The 2000 census, for instance, revealed more surviving individuals aged 10-14 in 2000 than those counted at ages $0-4$ in the 1990 census. It also displays a more balanced sex ratio among the same birth cohorts.

16 A preference for sons will influence the sex ratio at birth to any significant degree only if couples are resorting to sex-selective abortion. The reported sex ratio at birth may be influenced by gender-specific infanticide. Thus, the one-child policy affects the sex ratio to the extent that it encourages the use of these mechanisms to achieve the desired sex. 


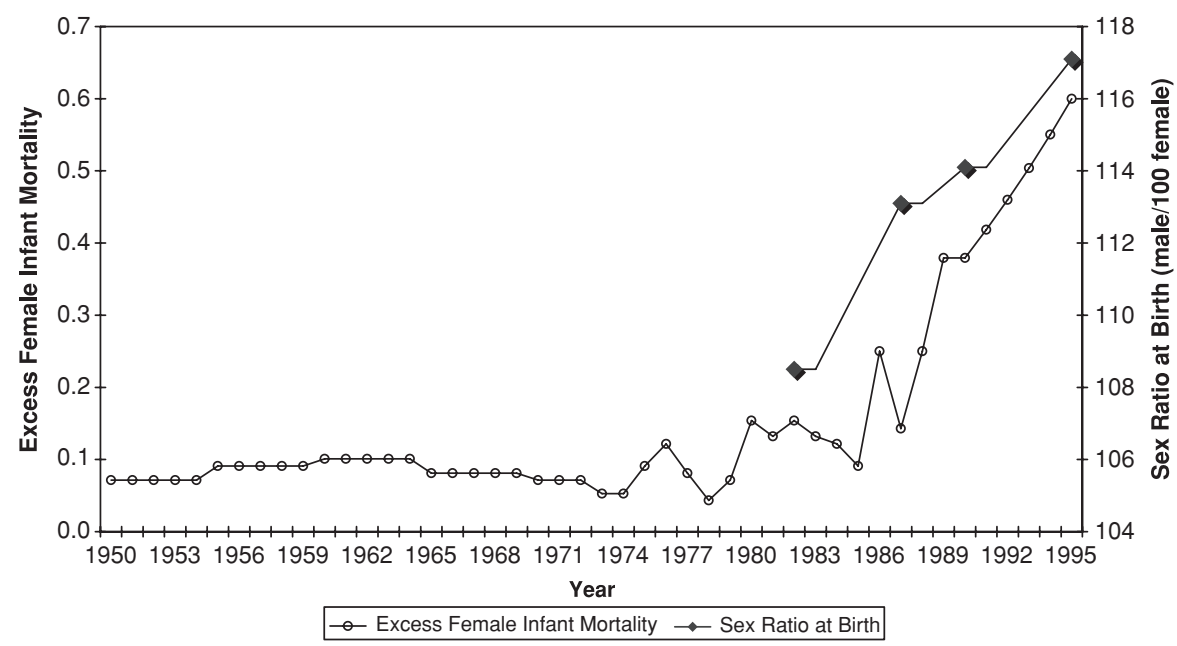

Figure 5.4. Rising sex ratio and excess female infant mortality, China

Underreporting, however, cannot account for all the missing girls and certainly not for most of the sharp increase in excess female infant mortality. It is common to avoid reporting the birth of a female child, but much less common to fake a female infant death. As indicated by the figures given in Table 5.1, while male infant mortality experienced two decades of consecutive decline, roughly 40 percent overall, female infant mortality declined by only about 15 percent, with all the reduction occurring during the 1990s. In 1982, Chinese female infant mortality was lower than that of males, similar to most populations without deliberate practices of gender discrimination against female babies, while in 1990 and 2000, the pattern was reversed.

A declining trend that can be traced to at least the mid-1930s (Coale and Banister, 1994) has been reversed, with excess female mortality at young ages on the rise following the implementation of the one-child policy. As shown in Figure 5.4, excess female infant mortality increased sharply, from around 10 percent in the late 1970 s to 60 percent in $1995 .{ }^{17}$ Whereas underreporting of female births may inflate the female mortality rate at young ages, it cannot explain all the increase in the ratio between male and female infant mortality, as underreporting exists for both male and female births, though more seriously in the case of females. Moreover, excess female mortality is not confined to the first year of life, but extends to the

17 Female excess infant mortality is calculated as the percentage of observed female infant mortality that is above the expected level. In the absence of deliberate human intervention, male infant mortality is normally higher than the female infant mortality rate, by about 20 percent. The expected level of female infant mortality is calculated by multiplying male infant mortality for the same period by a factor of 0.833 . 
young ages of $1-4$ as well (Choe, Hao, and Wang, 1995; Zhu and Li, 2003). ${ }^{18}$ Such an injustice to females so early in life is one of the most glaring forms of social inequality directly resulting from China's birth-control policy.

\section{Social Stratification in Marriage}

Demographic abnormalities caused by state policies may combine with other social forces to produce new forms of social inequality, such as increased social stratification in marriage. Public attention has focused on the likely effects of the rising sex ratio on marriage prospects for men. The reality is that poor Chinese men will likely be the only victims of the shortage of women.

In the last two decades, there has been a return of the sharply stratified marriage pattern by social status. Following decades of increasing male marriages, as reflected in a declining proportion of male bachelors at age 40 and the declining significance of social status in the likelihood of marriage (Wang and Tuma, 1993), male marriage once again has become an indicator of social privilege. In the early 1980s, whereas only 0.5 percent of university-educated men were unmarried by age 40 , 15.0 percent of illiterate or semiliterate peasants of the same age were still single. In 1990, the share of unmarried bachelors among the rural poor at age 40 rose to 19 percent (Lee and Wang, 1999, pp. 80-81). The most recent census reports that in 2000, nationally only 3.8 percent of males aged 40 were never married. Among those residing in the countryside, and those with the least amount of formal schooling, the percentage was 26.5. ${ }^{19}$ At the highest level of educational attainment, college and above, only 1 percent of men were bachelors. Such a social concentration of unmarried males may well worsen as cohorts with increasingly imbalanced sex ratios reach marriage age. In 2000, for instance, among the least educated 30-year-old males, about two in five, 44.8 percent, were still unmarried.

\section{Regional Disparities}

Regional demographic differences have become more pronounced in China as economic stratification deepens following the reforms. Differences between urban

18 One encouraging exception to this disturbing reversal of gender patterns is an observed improvement in female adult mortality. Between the ages of 25 and 50, while male mortality rates calculated from the 2000 census are no more than 10-20 percent below that in the 1990 census, female mortality rates are consistently more than 30 percent below the levels a decade ago (Li and Sun, 2003, p. 41; Figure 5.4). Both reduced childbearing and improved maternal health care can be credited for such an improvement.

19 This and other numbers on marriage are calculated from China's 2000 population census tabulations (Table 5.3, Long Form). The 2000 census used schooling level instead of literacy level as a measure of education for those with below a primary school education. The lowest schooling group here includes those who never attended school or attended only adult schools. Adding primary school educated to this group decreases the percentage to 10.98 , a number nearly three times the national average. 
and rural areas and between rich and poor provinces portray a demographic profile that resembles the whole world. China's most urbanized provinces have fertility levels that are well below the replacement level and are increasingly relying on a large influx of migrant laborers to sustain their economic growth. These provinces are also years ahead in terms of the health status of their populations, compared with poor provinces.

Estimates of life expectancy based on the 2000 census, for instance, show coexistence of a first and a third world in parts of the same country. In 2000, rural male and female Chinese residents had a life expectancy that was 7.4 and 8.0 percent below city residents (5.6 and 6.3 years, respectively). ${ }^{20}$ In 1981 , these gaps were at 5.0 and 6.0 percent and in 1989-1990, 3.6 and 5.5 percent. $^{21}$ These numbers cannot be interpreted simply as evidence of a growing health gap between urban and rural China because of changes in the urban-rural definition in the data. There is little doubt, however, that a persistent gap has existed. ${ }^{22}$ In 2000, just as in 1981 and 1990, life expectancy in China's most urbanized regions, the three centrally controlled coastal municipalities (Shanghai, Beijing, and Tianjin), exceeded those of China's poorest provinces and those with high concentrations of minority populations by more than ten years.

Moreover, as shown by the numbers given in Table 5.5, over a period of nearly twenty years, the mortality gap between these two extreme groups of Chinese provinces has not closed. While the poorest provinces are among those with the largest gains in life expectancy, the richest ones are also in this same group. Although it is more costly and more difficult to reduce mortality at a higher level of life expectancy, the improvement in life expectancy in China's poor provinces is rather modest in comparison with the richer provinces. ${ }^{23}$

In addition, published data on causes of death report that death due to respiratory diseases nearly doubled in rural China between 1980 and 2000, rising from 79 to 142 per 100,000 to become the leading cause of death during the last decade. In urban areas, respiratory disease ranked fourth, after cancer, cerebrovascular, and

${ }^{20}$ Chinese residing in cities (shi) had a male life expectancy of 74.95 and a female life expectancy of 79.2. Those residing in the countryside (xian), had life expectancies of 69.4 and 72.88 for males and females, respectively (Li and Sun, 2003, p. 43).

${ }^{21}$ In 1981, the city population had life expectancies of 69.08 and 72.74 for males and females, respectively; countryside populations had life expectancies of 65.56 and 68.36, respectively. In 1989-1990, life expectancies for males and females were at 70.1 and 75.05 for the urban population, versus rural life expectancies of 67.6 and 70.9 (China population statistics).

22 Urban life expectancy numbers in 1981 and 1989-1990 included population residing in towns (zhen), whereas the numbers in 2000 included population only in cities, not towns. Populations living in townships, who are not included in the 2000 urban numbers, had slightly lower life expectancies than those in cities ( 73.18 and 77.68 for males and females in townships, compared with those given in footnote 20).

23 According to the 2003 World Population Data Sheet published by the Population Reference Bureau (www.prb.org), life expectancy for developed world averaged seventy-six years and for less developed world (excluding China), sixty-three. 
Table 5.5. Mortality change in China's provinces during the reform era

\begin{tabular}{|c|c|c|c|c|c|c|c|}
\hline \multirow[b]{3}{*}{ Province } & \multicolumn{3}{|c|}{ Life expectancy level } & \multirow{2}{*}{\multicolumn{3}{|c|}{$\frac{\text { Percent of national level }}{\text { Year }}$}} & \multirow{3}{*}{$\begin{array}{l}\text { Life expectancy } \\
\text { index }(2000)\end{array}$} \\
\hline & \multicolumn{3}{|c|}{ Year } & & & & \\
\hline & 1981 & 1990 & 2000 & 1981 & 1990 & 2000 & \\
\hline Shanghai & 72.9 & 74.9 & 78.1 & 108 & 109 & 109 & 107 \\
\hline Beijing & 72.0 & 72.9 & 76.1 & 106 & 106 & 107 & 106 \\
\hline Tianjin & 70.9 & 72.3 & 74.9 & 105 & 105 & 105 & 106 \\
\hline Zhejiang & 69.6 & 71.8 & 74.7 & 103 & 105 & 105 & 107 \\
\hline Shandong & 70.1 & 70.6 & 73.9 & 104 & 103 & 104 & 105 \\
\hline Jiangsu & 69.6 & 71.4 & 73.9 & 103 & 104 & 104 & 106 \\
\hline Liaoning & 70.7 & 70.2 & 73.3 & 104 & 102 & 103 & 104 \\
\hline Guangdong & 71.3 & 72.5 & 73.3 & 105 & 106 & 103 & 103 \\
\hline Jilin & 69.0 & 68.0 & 73.1 & 102 & 99 & 102 & 106 \\
\hline Hainan & - & 70.0 & 72.9 & - & 102 & 102 & - \\
\hline Fujian & 68.6 & 68.6 & 72.6 & 101 & 100 & 102 & 106 \\
\hline Hebei & 70.5 & 70.4 & 72.5 & 104 & 103 & 102 & 103 \\
\hline Heilongjiang & 68.3 & 67.0 & 72.4 & 101 & 98 & 101 & 106 \\
\hline Anhui & 69.4 & 69.5 & 71.9 & 103 & 101 & 101 & 104 \\
\hline Shanxi & 67.8 & 69.0 & 71.7 & 100 & 101 & 100 & 106 \\
\hline Henan & 69.8 & 70.2 & 71.5 & 103 & 102 & 100 & 102 \\
\hline Guangxi & 70.2 & 68.7 & 71.3 & 104 & 100 & 100 & 102 \\
\hline Sichuan & 64.1 & 66.3 & 71.2 & 95 & 97 & 100 & 111 \\
\hline Hubei & 65.7 & 67.3 & 71.1 & 97 & 98 & 100 & 108 \\
\hline Hunan & 65.6 & 66.9 & 70.7 & 97 & 98 & 99 & 108 \\
\hline Ningxia & 65.7 & 66.9 & 70.2 & 97 & 98 & 98 & 107 \\
\hline Shaanxi & 65.0 & 67.4 & 70.1 & 96 & 98 & 98 & 108 \\
\hline Inner Mongolia & 66.8 & 65.7 & 69.9 & 99 & 96 & 98 & 105 \\
\hline Jiangxi & 66.1 & 66.1 & 69.0 & 98 & 96 & 97 & 104 \\
\hline Gansu & 65.9 & 67.2 & 67.5 & 97 & 98 & 94 & 102 \\
\hline Qinghai & 61.1 & 60.6 & 66.0 & 90 & 88 & 92 & 108 \\
\hline Guizhou & 61.6 & 64.3 & 66.0 & 91 & 94 & 92 & 107 \\
\hline Yunnan & 61.1 & 63.5 & 65.5 & 90 & 93 & 92 & 107 \\
\hline Xinjiang & 60.7 & 62.6 & 64.7 & 90 & 91 & 91 & 107 \\
\hline Tibet & - & 59.6 & 64.4 & - & 87 & 90 & - \\
\hline National & 67.67 & 68.55 & 71.40 & & & & 106 \\
\hline
\end{tabular}

Source: Life expectancy numbers for 1981 are from Mortality Statistics of CPIRC and for 1990 and 2000 are from Yearbook (2003, p. 117). Chongqing and Hainan provinces are not included due to their recent establishment.

heart diseases. In 2000, the death rate in rural China due to injury, trauma, and toxicosis more than doubled, compared with 1980 figures, and was twice as high than in urban areas (Zhao, 2007). These and other demographic disparities will no doubt further shape China's regional economies and require more interregional links. 


\section{CONCLUSION}

In many ways, China has always been a demographic early achiever. Its mortality rates declined early and rapidly under a socialist planned economy and public health system. In this regard, China was much more successful than most other countries with similar income levels. China's fertility also declined much faster and earlier in the development process than elsewhere - due partly to a government birth-control program that finds no equal in the extent to which it intruded on the reproductive decisions of couples.

Such a compressed demographic transition positioned China to reap a relatively large demographic dividend at an opportune time. China's first demographic dividend, deriving from fertility decline, materialized at the same time that China underwent its most radical economic transitions and faced the strongest unemployment pressures. The demographic factor was thus favorable in China's economic growth during the last quarter century.

Should one conclude that China's one-child policy was the right course of action? On several counts, the answer is no. First, fertility was declining rapidly even before the one-child policy was implemented; thus, only a small portion of the first dividend can be attributed to the policy per se. Second, more rapid economic growth came with a potentially large and unmeasured cost. Parents were forced to have fewer children than they wanted. There is no reason to suppose that the economic gains outweighed the direct costs on parents who suffered under the onechild policy. Third, analysis that focuses exclusively on the record to date would also be fundamentally flawed, because the economic implications of demographic change will be felt for decades to come.

Being an early achiever brings with it a cost. As we have discussed earlier, as consequences of such a forced demographic transition, China will soon enter a long period of decline in labor supply and face a rapid increase in the elderly population that cannot be reversed easily and quickly. Whereas this aging process may bring with it a second demographic dividend, this favorable outcome depends heavily on the achievement of a suitable institutional environment. State-enforced fertility decline has also resulted in a collapse of the birth statistics collection system, caused a sustained and sharp increase in the sex ratio and in excess female mortality at young ages, and forcefully altered the kinship structure for many Chinese families. These social costs are not only severe but also long lasting.

Moreover, many of the demographic challenges that China faces in the future will vary sharply by region. China's rapid aging process, for example, will not take place evenly across the country, but will vary widely across different locales due to the history of differential birth-control policies. Urban and rural China, as well as China's different regions, vary in almost every demographic aspect: fertility, mortality, age structure, and migration patterns. These demographic differences will play an important role in defining China's future economic and social landscape 
and will simultaneously increase the need for interregional exchange and interdependence.

\section{APPENDIX: CALCULATING THE DEMOGRAPHIC DIVIDEND}

\section{THE FIRST DIVIDEND}

Given the age profile of production, an increase in the population concentrated at high-productivity ages must lead to an increase in per capita output. The extent to which the standard of living rises as a consequence may be exaggerated, however, because consumption, and indeed physiological needs, also varies by age.

The effects of age variation in production and consumption are easily incorporated into a simple neoclassical growth model (Cutler et al., 1990; Mason and Lee, forthcoming). Define the effective number of producers as $L(t)=$ $\sum_{a} w(a) P(a, t)$, where $w(a)$ measures age variation in productivity and $P(a, t)$ is the population of age $a$ in year $t$. The effective number of consumers is defined in similar fashion as $N(t)=\sum_{a} c(a) P(a, t)$. Output per effective consumer, $y(t)$, is

$$
\frac{Y(t)}{N(t)}=\frac{L(t)}{N(t)} \times \frac{Y(t)}{L(t)}
$$

or the product of the support ratio $(L / N)$ and output per worker $(Y / L)$.

The rate of growth in output per effective consumer $(\dot{y})$ is equal to the rate of growth of the support ratio (the excess of the rate of growth in the effective labor force over the rate of growth of the effective number of consumers) and the rate of growth of output per effective producer $\left(\dot{y}^{l}\right)$ :

$$
\dot{y}(t)=\dot{L}(t)-\dot{N}(t)+\dot{y}^{l}(t) .
$$

The first dividend is captured by changes in the support ratio, that is, the first two right-hand-side terms in equation (5.2).

Computation of the support ratio requires estimates of age-specific productivity and consumption weights. These are estimated for China using the 2000 Urban Survey of Income and Expenditure. The productivity weights are assumed to be proportional to labor income and the consumption weights are assumed to be proportional to estimated consumption.

\section{THE SECOND DIVIDEND}

The concept of life cycle wealth and its relationship to population age structure is central to understanding the second demographic dividend. The lifetime budget constraint implies that the current life cycle wealth of an individual, a cohort, or a population must equal the present value of the future stream of consumption less 
the present value of the future stream of labor income. ${ }^{24}$ In the absence of intergenerational transfers (familial support, PAYGO pension systems, bequests, etc.), life cycle wealth consists entirely of capital, that is, real assets held by each individual, a cohort, or the population. Capital represents one form of life cycle wealth.

Transfer systems create another form of life cycle wealth for its participants transfer wealth, the present value of net lifetime transfers received by an individual, a cohort, or a population. A familiar example of transfer wealth is social security or pension wealth that arises from PAYGO pension programs and consists of the present value of benefits to be received in the future less the present value of taxes to be paid in the future. A less familiar example of transfer wealth arises from childrearing. During childhood, individuals receive transfers directly from parents or indirectly from taxpayers - schooling, for example. When they become adults, individuals make transfers to children, directly to their own children or indirectly to all children in their capacity as taxpayers. Childrearing transfer wealth is the net present value of all transfers associated with childrearing.

Life cycle wealth is closely related to the direction of resource flows. The life cycle wealth associated with upward flows - from younger age groups to older age groups - is positive. Current members of the population can expect to receive more in benefits than they pay in costs in present value terms. This is possible because the current population's wealth includes transfers that will be received from generations that are not yet born. The flip side of transfer wealth is the implicit debt imposed on future generations.

The life cycle wealth associated with downward flows - from older age groups to younger age groups - is negative. Many members of the population have already received benefits but they have not yet incurred the costs associated with downward transfers. A newly married couple, for example, faces childrearing costs but may anticipate few additional transfers from their parents. Hence, their childrearing life cycle wealth is strongly negative.

Changes in age structure have a major influence on aggregate life cycle wealth. As shown earlier, China's young age structure in 1982 must have led to resource flows that were strongly downward. China's projected age structure in 2050 will lead to resource flows that are strongly upward under the assumptions stated earlier. As a result, the changes in age structure will lead to a shift from negative to positive life cycle wealth.

The relationship between life cycle wealth and age structure can be readily summarized given sufficiently strong assumptions. Lee (1994) has shown that given steady-state, golden-rule growth, the ratio of life cycle wealth $(W)$ to labor income (or consumption) is equal to the difference between the mean age of producing and the mean age of consuming $\left(A_{Y^{l}}-A_{C}\right)$ :

$$
\frac{W}{Y^{l}}=\frac{W}{C}=A_{Y^{l}}-A_{C},
$$

${ }^{24}$ Any bequests are included in consumption. 
where the mean ages of producing and consuming are

$$
\begin{aligned}
A_{Y^{l}} & =\int_{0}^{\omega} a N(a) Y^{l}(a) \mathrm{d} a / \int_{0}^{\omega} N(a) Y^{l}(a) \mathrm{d} a \\
A_{C} & =\int_{0}^{\omega} a N(a) C(a) \mathrm{d} a / \int_{0}^{\omega} N(a) C(a) \mathrm{d} a .
\end{aligned}
$$

The mean ages are "dollar-weighted" average ages. The difference between the two measures the lag in years between the age at which a dollar is earned and the age at which it is consumed. The greater this lag, the greater is life cycle wealth. If the population consumes before it produces, on average, its life cycle wealth is negative.

\section{References}

Banister, Judith and Samuel H. Preston. 1981. "Mortality in China." Population and Development Review. 7(1), pp. 98-110.

Bloom, David E., David Canning, and Jaypee Sevilla. 2002. The Demographic Dividend: A New Perspective on the Economic Consequences of Population Change. Santa Monica, CA: RAND.

Bloom, David E., David Canning, and Bryan Graham. 2003. "Longevity and Life-Cycle Savings.” Scandinavian Journal of Economics. 105(3), pp. 319-338.

Bloom, David E. and Jeffrey G. Williamson. 1998. "Demographic Transitions and Economic Miracles in Emerging Asia." World Bank Economic Review. 12(3), pp. 419-456.

Cai,Yong. Forthcoming. "Assessing Fertility Levels in China Using Variable-r Method." Demography.

Cai, Yong and William Lavely. 2003. "China's Missing Girls: Numerical Estimates and Effects on Population Growth.” The China Review. 3, pp. 13-29.

Chan, Kam Wing. 2001. "Recent Migration in China: Patterns, Trends, and Policies." Asian Perspectives. 25(4), pp. 127-155.

Chan, Kam Wing and Li Zhang. 1999. "The Hukou System and Rural-Urban Migration: Processes and Changes.” The China Quarterly. 160(1), pp. 818-855.

Chan, Kam Wing and Ying Hu. 2003. "Urbanization in China in the 1990s: New definition, Different Series, and Revised Trends." The China Review. 3(2), pp. 49-71.

Choe, Minja K., Hongsheng Hao, and WANG Feng. 1995. "The Effect of Gender and Other Factors on Child Survival in China." Social Biology. 42(1-2), pp. 50-64.

Coale, Ansley J. 1984. Rapid Population Change in China, 1952-1982. Committee on Population and Demography, Report 27. Washington, DC: National Academy Press.

Coale, Ansley J. and Judith Banister. 1994. "Five Decades of Missing Females in China." Demography. 31(3), 459-479.

Coale, Ansley J. and Shengli Chen. 1987. Basic Data on Fertility in the Provinces of China, 1942-1982. Honolulu: East-West Population Institute Paper Series.

Cutler, David M., James M. Poterba, Louise M. Sheiner, Lawrence H. Summers. 1990. “An Aging Society: Opportunity or Challenge?” Brookings Papers on Economic Activity. (1), pp. 1-56. 
Davis, Deborah S. 2000. "A Revolution in Consumption," in The Consumer Revolution in Urban China. Deborah S. Davis, ed. Berkeley: University of California Press, pp. 122.

Deaton, Angus and Christina H. Paxson. 2000. "Growth, Demographic Structure, and National Saving in Taiwan," in Population and Economic Change in East Asia, A Supplement to Population and Development Review, vol. 26. R. Lee and C. Y. C. Chu, eds. New York: Population Council, pp. 141-173.

Feeney, Griffith and WANG Feng. 1993. "Parity Progression and Birth Intervals in China: Policy Initiatives and Demographic Responses." Population and Development Review. 19(1), pp. 61-101.

Greenhalgh, Susan. 1986. "Shifts in China's Population Policy, 1984-86: Views from the Central, Provincial, and Local Levels." Population and Development Review. 12, pp. 491515.

Greenhalgh, Susan, Chuzhu Zhu, and Nan Li. 1994. "Restraining Population Growth in Three Chinese Villages, 1988-93." Population and Development Review. 20, pp. 365-395.

$\mathrm{Gu}$, Baochang, WANG Feng, Zhigang Guo, and Erli Zhang. 2007. "China’s Local and National Fertility Policies at the End of the Twentieth Century." Population and Development Review 33(1):129-147.

Guo, Zhigang, 2000. "Cong jinnian lai de shiqi shengyu xingwei kan zhongsheng shengyu shuiping [Examining Life-Time Fertility Level from Period Fertility Behavior of Recent Years]," Renkou yanjiu [Population Research]. 24(1), pp. 7-18.

Guo, Zhigang and Wei Chen. 2007. "Below Replacement Fertility in Mainland China," in Transition and Challenge: China's Population at the Beginning of the $21^{\text {st }}$ Century. Zhongwei Zhao and Fei Guo, eds. Oxford: Oxford University Press, pp. 54-70.

Higgins, Michael and Jeffrey G. Williamson. 1997. "Age Structure Dynamics in Asia and Dependence on Foreign Capital." Population and Development Review. 23(2), pp. 261293.

Kaufman, Joan. 2003. "Myths and Realities of China’s Population Program.” Harvard Asia Quarterly. 7(1), pp. 21-25.

Kelley, Allen C. and Robert M. Schmidt. 1996. "Saving, Dependency and Development.” Journal of Population Economics. 9(4), pp. 365-386.

Kinugasa, Tomoko. 2004. "Life Expectancy, Labor Force, and Saving." Ph.D. Dissertation, University of Hawaii, Manoa.

Lavely, William, James Lee, and WANG Feng. November 1990. "Chinese Demography: The State of the Field." Journal of Asian Studies. 49.4, pp. 807-834.

Lee, James and WANG Feng. 1999. One Quarter of Humanity: Malthusian Mythology and Chinese Realities, 1700-2000. Cambridge, MA: Harvard University Press.

Lee, Ronald D. 1994. "The Formal Demography of Population Aging, Transfers, and the Economic Life Cycle," in Demography of Aging. L. G. Martin and S. H. Preston, eds. Washington, DC: National Academy Press, pp. 8-49.

Lee, Ronald D. 2000. "Intergenerational Transfers and the Economic Life Cycle: A Crosscultural Perspective," in Sharing the Wealth: Demographic Change and Economic Transfers between Generations. A. Mason and G. Tapinos, eds. Oxford: Oxford University Press, pp. $17-56$.

Lee, Ronald D., Andrew Mason, and Tim Miller. 2003. "From Transfers to Individual Responsibility: Implications for Savings and Capital Accumulation in Taiwan and the United States." Scandinavian Journal of Economics. 105(3), pp. 339-357.

Li, Shuzhuo and Fubin Sun. 2003. "Mortality Analysis of China's 2000 Population Census Data: A Preliminary Examination.” The China Review. 3(2), pp. 31-48. 
Liang, Zai. 2003. "Internal Migration in China: Data Sources, Recent Patterns, and a New Research Agenda." Paper presented at the Workshop on Recent Demographic Changes in China, Canberra, Australia.

Mason, Andrew. 1987. "National Saving Rates and Population Growth: A New Model and New Evidence," in Population Growth and Economic Development: Issues and Evidence. Social Demography series. D Gale Johnson and Ronald D. Lee, eds. Madison, WI: University of Wisconsin Press, pp. 523-560.

Mason, Andrew. 1988. "Saving, Economic Growth, and Demographic Change.” Population and Development Review. 14(1), pp. 113-144.

Mason, Andrew. 2001. Population Change and Economic Development in East Asia: Challenges Met, Opportunities Seized. Stanford: Stanford University Press.

Mason, Andrew and Ronald Lee. 2006. "Reform and Support Systems for the Elderly in Developing Countries: Capturing the Second Demographic Dividend.” GENUS. LXII(2): $11-35$.

Merli, Giovanna M. 1998. "Underreporting of Births and Deaths in Rural China: Evidence from Field Research in One County of Northern China." The China Quarterly. 155, pp. 637-655.

Merli, Giovanna M. and Adrian E. Raftery. 2000. “Are Births Underreported in Rural China? Manipulation of Statistical Records in Response to China's Policies.” Demography. 37(1), pp. 109-126.

Merli, Giovanna M. and Herbert L. Smith. 2002. "Has the Chinese Family Planning Policy Been Successful in Changing Fertility Preferences?” Demography. 39(3), pp. 557-572.

Merli, Giovanna M., Qian Zhenchao, and Herbert L. Smith. 2004. "Adaptation of a Political Bureaucracy to Economic and Institutional Change under Socialism: The Chinese State Family Planning System." Politics and Society. 32(2), pp. 231-256.

Retherford, Robert, Minja K. Choe, Jiajian Chen, Xiru Li, and Hongyan Cui. 2005. "Fertility in China: How Much Has It Really Declined?” Population and Development Review. 19(1), pp. 57-84.

Scharping, Thomas. 2003. Birth Control in China 1949-2000, Population Policy and Demographic Development. London and New York: Routledge Curzon.

Scharping, Thomas. 2007. "The Politics of Numbers: Fertility Statistics in Recent Decades," in Transition and Challenge: China's Population at the Beginning of the $21^{\text {st }}$ Century. Zhongwei Zhao and Fei Guo, eds. Oxford: Oxford University Press, pp. 34-53.

Smith, Herbert L. 1994. "Nonreporting of Births or Nonreporting of Pregnancies? Some Evidence from Four Rural Counties in North China." Demography. 31(3), pp. 481-486.

Solinger, Dorothy J. 1999. Contesting Citizenship in Urban China: Peasant Migrants, the State, and the Logic of the Market. Berkeley: University of California Press.

Solow, Robert M. 1956. "A Contribution to the Theory of Economic Growth.” Quarterly Journal of Economics. 70(1), pp. 65-94.

Tobin, James. 1967. "Life Cycle Saving and Balanced Economic Growth," in Ten Economic Studies in the Tradition of Irving Fisher. William Fellner, ed. New York: Wiley, pp. 231256.

United Nations, P. D. 2003. World Population Prospects: The 2002 Revision. New York: United Nations. Population Division.

WANG Feng. 2005. "Can China Afford to Continue its One-Child Policy?” Asia Pacific Issues, vol. 17. Honolulu: East-West Center, pp. 1-12.

WANG Feng and Nancy Tuma. 1993. "Changes in Chinese Marriage Patterns during the Twentieth Century." Proceedings of the XXIInd General Conference of the IUSSP. 3, pp. 337352. 
WANG Feng, Xuejin Zuo, and Danching Ruan. 2002. "Rural Migrants in Shanghai: Living under the Shadows of Socialism." International Migration Review. 36(2), pp. 520-545.

Willis, Robert J. 1988. "Life Cycles, Institutions and Population Growth: A Theory of the Equilibrium Interest Rate in an Overlapping-Generations Model," in Economics of Changing Age Distributions in Developed Countries. R. D. Lee, W. B. Arthur, and G. Rodgers, eds. Oxford: Oxford University Press, pp. 106-138.

Winkler, Edwin A. 2002. "Chinese Reproductive Policy at the Turn of the Millennium: Dynamic Stability.” Population and Development Review. 28(3), pp. 379-418.

World Bank. 2004. World Development Indicators 2004. New York: World Bank.

Yan Rui and Chen Shengli, 1993. "Sishi nianlai Zhongguo renkou fen nianling siwanglu yu shouming de yanjiu [Age-Specific Mortality Rates and Life Expectancy in China in the Last 40 Years]," Zhongguo shengyu jieyu chouyang diaocha Beijing guoji yantaohui lunwenji [Proceedings of the International Conference on China's Fertility and Birth Control Sample Survey]. Beijing: Zhongguo renkou chubanshe, pp. 510-529.

Yearbook. 2003. Zhongguo tongji nianjian [China Statistical Yearbook]. Beijing: China Statistics Press.

Zeng, Yi. 1996. “Is Fertility in China in 1991-1992 Far below Replacement Level?” Population Studies. 50, pp. 27-34.

Zeng, Yi and Zhenglian Wang. 2003. "Dynamics of Family and Elderly Living Arrangements in China: New Lessons Learned from the 2000 Census." The China Review. 3(2), pp. 95119.

Zhang, Guangyu and Zhongwei Zhao. 2006. "Reexamining China's Fertility Puzzle: Data Collection and Quality Over the Last Two Decades," Population and Development Review 32(2), pp. 293-321.

Zhang Guangyu and Yuan Xing, 2004. "Dui 1990 niandai chushengloubao he shengyushuiping gujiwenti de sikao" [Some Thoughts on Birth Underreporting and Estimated Fertility Level in the 1990s]," Renkou yanjiu [Population Research]. (3), pp. 29-36.

Zhao, Zhongwei. 2007. "Changing Mortality Patterns and Causes of Death," in Transition and Challenge: China's Population at the Beginning of the $21^{\text {st }}$ Century. Zhongwei Zhao and Fei Guo, eds. Oxford: Oxford University Press, pp. 160-176.

Zhu Chuzhu and Li Shuzhuo, 2003. "guan ainuhai, baohu nuhai [Love Girls and Protect Girls]," Renkou yanjiu [Population Research]. (5), pp. 50-52. 